\title{
Comparative Investigations of the Influence of Polyvalent Alcohols and Fruit Extracts on the Physicochemical Properties of Tobacco
}

by

\author{
A. Stoilova, M. Kratchanova, Cbr. Kratcbanov
}

Higher Institute of Food and Flavour Industry, 4000 Plovdiv, Bulgaria

\section{SUMMARY}

Laboratory investigations have been carried out into the application of water pectin extracts from dry apple pressings and orange peels as a moisture-retentive substance for use with tobacco from the unaromatized Rodopi blend.

It has been established from comparative experiments with extracts, water pectin solutions: and commonly applied humectants such as glycerol, diethylene glycol and propylene glycol that fruit pectin extracts can be used as humectants in tobacco production.

The increase in the pectin content of the extract improves the moisture-retentive ability of tobacco, as does the addition of enzyme hydrolysate to the extract. The type of extracting acid has a definite effect. Tobacco treated with a nitric acid extract has better moisture absorption properties. The extracts decrease the tar and carbon monoxide deliveries in tobacco smoke compared to the usual humectants, glycerol, diethylene glycol and propylene glycol.

The application of pectin extracts has a greater effect than the application of pure pectin solutions on the moisture-retentive properties of tobacco and the composition of tobacco smoke.

Received: 18th December 1992 - sccepted: 17th Msy 1993

\section{ZUSAMMENFASSUNG}

Es wurde untersucht, inwieweit Wasser-Pektin Extrakte aus gepreßtem trockenen Apfelkonzentrat und Orangenschalen bei der Tabakverarbeirung (unaromatisierter Rodopi Blend) als Feuchtigkeit speichernde Substanz verwendet werden können. Vergleichende Experimente mit diesen Fruchtextrakten, WasserPektin-Lösungen und allgemein üblichen Feuchthaltemitteln wie Glycerol, Diethylenglykol und Propylenglykol haben gezeigt, daß Pektinextrake aus Früchten als Feuchthaltemittel bei der Tabakverarbeitung genützt werden können. Ein höherer Pektingehalt des Extraktes führt zu einer besseren Speicherung der Feuchtigkeit in Tabak, was auch durch den Zusatz eines Enzymhydrolysats zum Extrakt erreicht werden kann. Die zur Extraktion verwendete Säure hat entscheidenden Einfluß. Tabak, der mit einem Salpetersäureextrakt behandelt wurde, hat bessere feuchtigkeitsabsorbierende Eigenschaften. Pektinextrakte verringern den Teer- und Kohlenmonoxidgehalt. im Tabakrauch im Vergleich zu den sonst üblichen Feuchthaltemitteln Glycerol, Diethlenglykol und Propylenglykol. Durch die Verwendung von Pektinextrakten werden die feuchtigkeitsspeichernden Eigenschaften des Tabaks verbessert und die Zusammensetzung von Tabakrauch positiver beeinflußt im Vergleich zu reinen Pektinlösungen. 


\section{RESUME}

Des études ont été réalisées en labotatoire pour déterminer les possibilités d'utilisation des extraits de pectine obtenus à partir de marcs de pommes séchés et d'écorces d'oranges en tant que substances susceptibles d'améliorer la rétention de l'humidité dans le tabac (en l'occurrence 'Rodopi blend' non aromatisé). Il ressort des expériences comparatives effectuées avec ces extraits de fruits, des solutions aqueuses de pectine et des humectants couramment employés, tels que le glycérol, le diéthylèneglycol et le propylèneglycol, que les extraits de pectine de fruits peuvent être utilisés comme humectants dans la production du tabac. L'augmentation de la teneur en pectine de l'extrait favorise la tétention de l'humidité par le tabac de la même manière que l'addition d'hydrolysat enzymatique à l'extrait. La nature de l'acide utilisé pour l'extraction a un effet déterminant. Ainsi le tabac traité par un extrait à l'acide nitrique présente-t-il de meilleures propriétés hygroscopiques. Comparativement aux humectants courants (glycétol, diéthylèneglycol et propylèneglycol), les extraits de pectine font diminuer la teneur de la fumée du tabac en goudrons et en monoxyde de carbone. L'utilisation des extraits de pectine se révèle d'une efficacité supérieure à celle des solutions de pectine pure tant à l'égard des propriétés hygroscopiques du tabac que de la composition de la fumee.

\section{INTRODUCTION}

Moisture-retentive substances are widely used in cigarette production. Their application is of great signifcance for the consumption of tobacco and the cigarette quality.

The most often used moisture-retentive substances or the so-called humectants are glycerol, 1,2-propylene glycol, diethylene glycol, sorbitol, 1,3-butylene glycol, triethylene glycol, etc. (1-5). The moisture-retentive action of these substances is due to their hygroscopicity, to better wetting as a result of decreased water surface tension, to their ability to dissolve the resins on the surface and to penetrate tobacco more easily. Certain substances intended for tobacco casing such as honey, sugar, molasses, fruit syrups, etc., also have a moisture-retentive effect. The role of the soluble carbohydrates constituting these products for improving the flavour properties of tobacco and increasing its hygroscopic properties has been established (6-8). Water mixtures have been developed for tobacco moistening based on substances with carbohydrate composition (9-12). The hygroscopic properties of tobacco are also due to the colloidal biopolymer complexes of the plant tissue: pectic substances, proteins, cellulose, etc. Their effect in relation to tobacco moisture is due to an increase in the adsorption connected moisture and a decrease in the capillary bonded water. Thus, experiments have been carried out for the application of low esterified apple pectin as a moisture-retentive agent in cigarette production, proving its efficiency in comparison with diethylene glycol (13). A patent has been obtained for coating tobacco leaves with cellulose derivatives in order to prevent them from drying (14). The fruit extracts combine the favourable properties of pectin solutions and casing substances. We obtained encouraging results from the application of water pectin extracts from dry apple pressings as a moisture-retentive agent in cigarette production (15). It was of interest to carry out comparative model investigations under laboratory conditions to study the effect of water pectin extracts on the physicochemical properties of tobacco. We investigated extracts from apple pressings and orange peels, water pectin solutions and the humectants commonly used: propylene glycol, glycerol and diethylene glycol.

\section{MATERIALS AND METHODS}

The experiments were carried out using industrially cut tobacco from the unaromatized Rodopi blend. The following substances were used as moisture-retentive agents: glycerol, diethylene glycol, propylene glycol and water solutions of apple pectin and fruit extracts. The traditional humectants were added to the tobacco mass in a dose of $2 \%$ and $3 \%$ diluted with water to $1: 2$ and $1: 1$, respectively. The apple pectin solutions and the extracts were added in quantity of $6 \%$ to the tobacco mass. A sample with water added in the same quantity of $6 \%$ was used as the control (untreated control). The water extracts were obtained from dry apple pressings and fresh orange peels which were waste materials from juice production. Water solutions of the following acids were used for the extraction: nitric, phosphoric and citric acid because of the expected effect of nitrates, phosphates and citrates on tobacco smoke composition. The extracts were obtained under the following conditions: $100 \mathrm{~g}$ dry apple pressings (or $300 \mathrm{~g}$ fresh orange peels) were mixed with $1500 \mathrm{ml}$ hot aqueous acid solution $\left(\mathrm{t}=80^{\circ} \mathrm{C}\right.$, extracting time 60 minutes) at $\mathrm{pH}=1.8$ for the extracts with nitric and phosphoric acid and 2.7 for the extracts with citric acid. After filtering and cooling the extracts were neutralized to $\mathrm{pH}=3.5$ using sodium carbonate. The extracts were analyzed for pectin content after coagulation with ethanol (16). The desired pectin concentra- 
tion of the extracts were obtained by dilution with water. Part of them were mixed with enzyme hydrolysate obtained by processing the exhausted apple pressings with cellulase and pectinase after extracting the pectin. The enzyme hydrolysis was carried out at a temperature of $50^{\circ} \mathrm{C}$ for 2 hours using $1 \mathrm{~g}$ of pectinase with PGA (200 000 units/g) and $2.2 \mathrm{~g}$ of cellulase (55 units/g) per $100 \mathrm{~g}$ of substrate. The hydrolysates were heated at a temperature of $80^{\circ} \mathrm{C}$ for 10 minutes to inactivate the enzymes.

The addition of the respective humectant to the tobacco was carried out in the following way: the tobacco samples in quantity of $1 \mathrm{~kg}$ were placed in plastic bags and heated in a thermostat up to $55^{\circ} \mathrm{C}$. After that a preheated solution $\left(60^{\circ} \mathrm{C}\right)$ was sprayed uniformly over them in a fine mist, using a pulverizer. The processed tobacco was once again heated in a thermostat at a temperature of $50^{\circ} \mathrm{C}$. After cooling the sample and normalizing the moisture content, uniform amounts of tobacco were taken from each sample for testing and making cigarettes. Plain cigarettes $(69 \mathrm{~mm}$ long) were produced using a laboratory cigarette machine (Hauni). The equilibrium moisture of the treated tobaccos was determined using a static method at a relative ambient air humidity of $63 \%$ and temperature of $22{ }^{\circ} \mathrm{C}$. The chemical indices of tobacco were determined using the respective methods: nicotine after ISO standard (17), protein substances after Mohr's method, total nitrogen after Kjeldahl's method, soluble carbohydrates and reducing substances after the method of Shoorl.

The chemical composition of tobacco smoke was determined for the cigarettes (nicotine, tar and carbon monoxide) using methods which correspond to standards of ISO (18-20). Tar is expressed water and moisture free.

\section{RESULTS AND DISCUSSION}

While studying the influence of extracts on tobacco and tobacco smoke special attention was paid to the following factors: extracting acid, pectin concentration and type of raw material for obtaining the extracts. The apple extracts obtained with nitric acid contributed to achieving a higher equilibrium moisture of tobacco compared to the extracts of phosphoric and citric acids (Table 1). There was no clearly-expressed tendency for the influence of extracting acids on the chemical composition of tobacco and tobacco smoke, since the small differences in the values of the investigated indices were within experimental error.

The pectin concentrations in the extract had a similar effect on the chemical composition of tobacco and tobacco smoke. The equilibrium moisture of tobacco increased with increasing the pectin content in the extract.

The influence of orange peel extracts (Table 2) on the equilibrium moisture, and the chemical composition of tobacco and tobacco smoke was similar to that of apple pressings (Table 1). Consequently, the two types of investigated raw materials were of equal importance for obtaining the extracts. Our investigations were carried out with extracts from apple pressings because of the greater availability of this raw material.

The conclusions from the comparative investigations of traditional humectants and apple extracts with $0.5 \%$ of pectin (Table 3) were that glycerol, diethyleneglycol and propylene glycol increased to a great extent the moisture-retentive properties of tobacco, expressed by the equilibrium moisture index. Glycerol had the greatest efficiency in this respect when added in a quantity of $3 \%$. The extract obtained with nitric acid was equivalent to diethylene glycol $(2 \%)$ and the extract obtained with citric acid to propylene glycol (2 $\%$ ). Compared to the control sample the extracts increased the tobacco equilibrium moisture by $0.5 \%$ to $1.1 \%$, and compared to the traditional humectants their influence on tobacco moisture retention was similat to the smaller dose of humectant ( $2 \%)$.

The chemical composition of tobacco was similar both for the tobaccos treated with humectants and for the control sample treated with water.

It was established from smoke analysis that in comparison with glycerol, diethylene glycol and propylene glycol the extracts decreased the delivery of tar and carbon monoxide, although in comparison with the untreated control sample the differences were insignificant. The delivery of nicotine did not change except for the sample with $3 \%$ glycerol.

It was established from the comparative studies on the influence of apple pectin solutions and apple extracts that the solutions and extracts applied did not significently change the chemical composition of tobacco (Table 4). The data on the moisture-absorption properties of tobacco and the composition of tobacco smoke may be explained on the basis that substances such as sugars, salts, are present in the extracts.

The positive influence of the extracts on tobacco (as indicated by the improvement of its moisture absorption properties and the chemical composition of smoke) could be intensified by adding to them substances contributing to their better assimilation and the more complete expression of their properties. We studied the influence of mixtures from a 1:1 extract with enzyme hydrolyzate from fruit mass, extract with $5 \%$ ethyl alcohol and a $1: 1$ mixture of extract and $0.5 \%$ solution of sodium nitrate. The pectin concentration in the mixtures was $0.5 \%$. The results are given in Table 5 . The data indicate that the addition of hydrolyzate in the extracts increased the equilibrium moisture of 


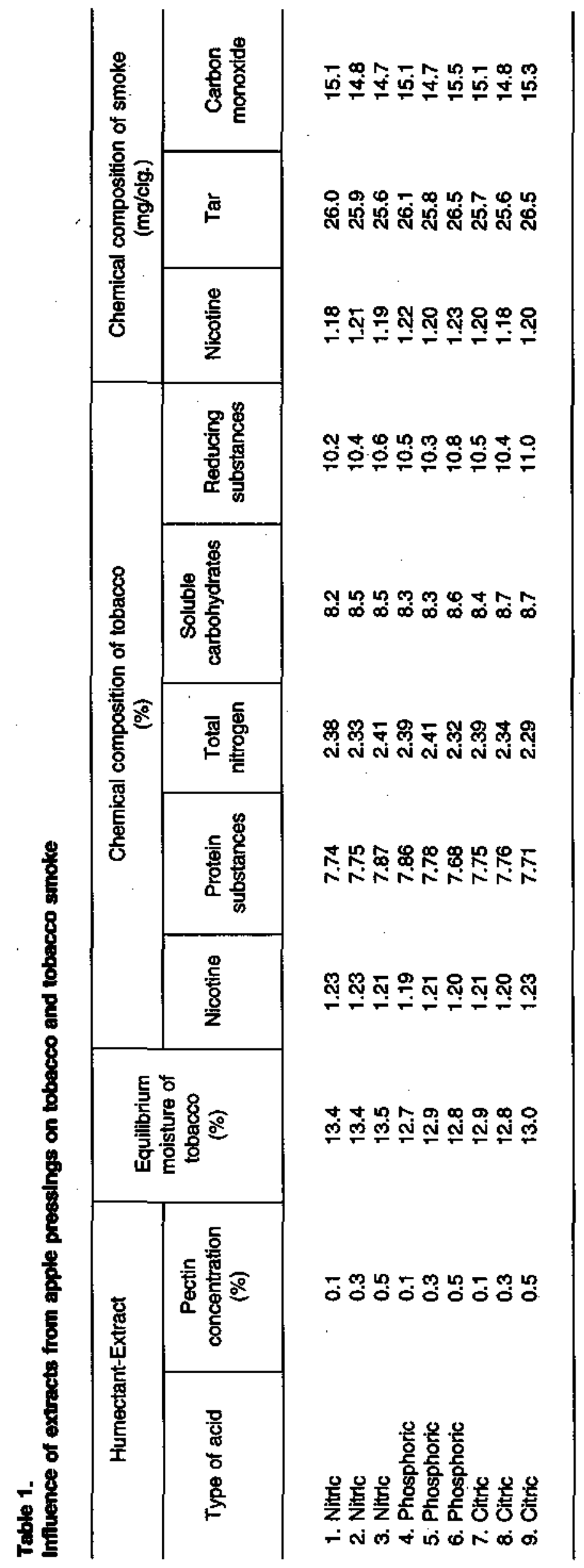




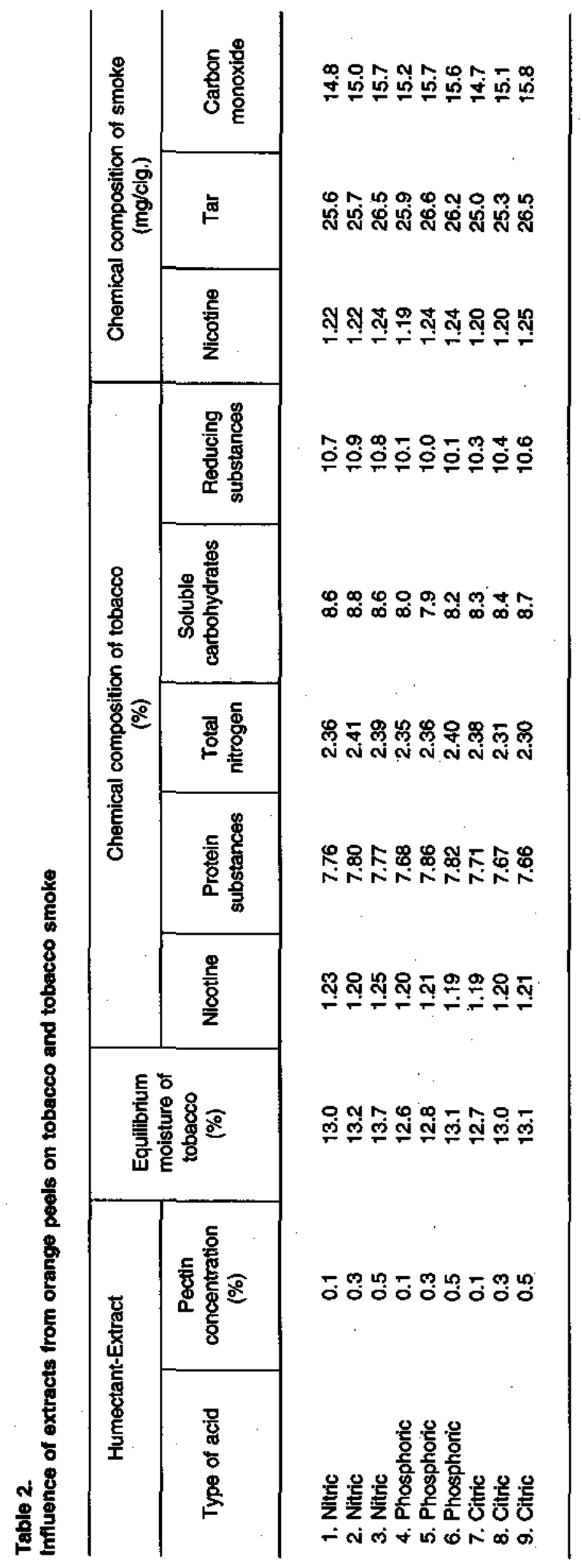




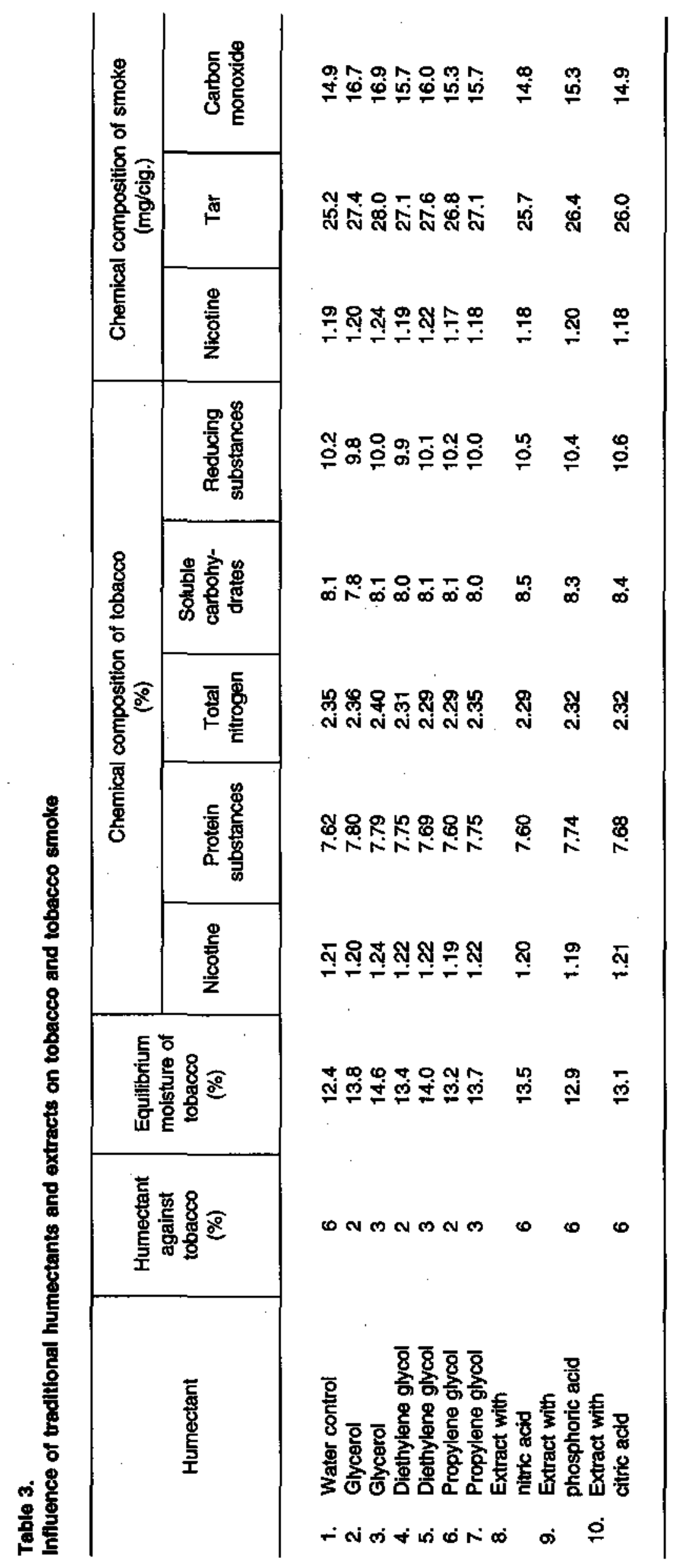




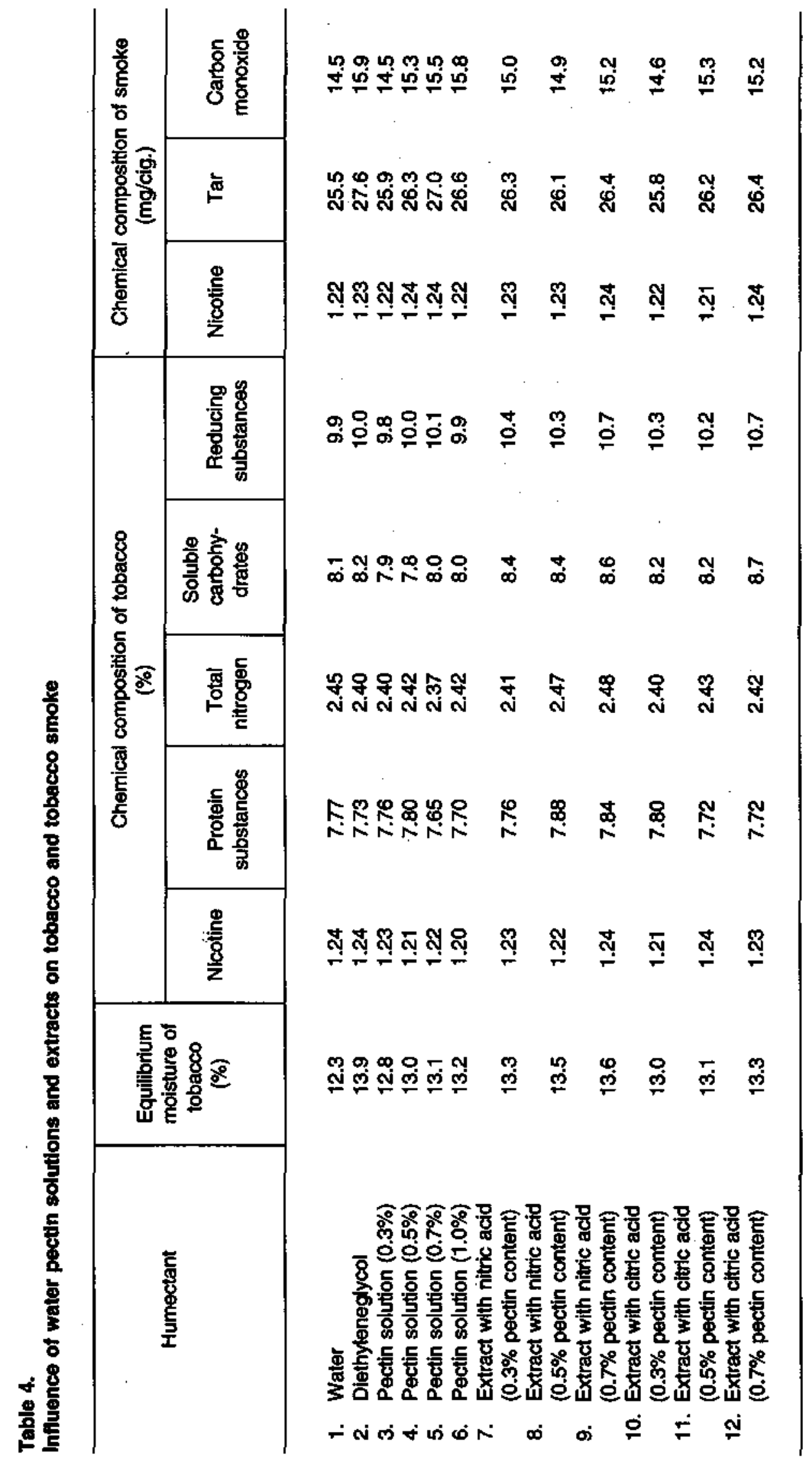


Table 5.

Influence of the addition of some substances to the extracts on tobacco and tobacco smoke.

\begin{tabular}{|c|c|c|c|c|c|}
\hline \multirow{2}{*}{\multicolumn{2}{|c|}{ Humectant }} & \multirow{2}{*}{$\begin{array}{l}\text { Equilibrium } \\
\text { moisture of } \\
\text { tobacco } \\
(\%)\end{array}$} & \multicolumn{3}{|c|}{$\begin{array}{l}\text { Chemical composition of smoke } \\
\text { (mg/cig.) }\end{array}$} \\
\hline & & & Nicotine & Tar & $\begin{array}{l}\text { Carbon } \\
\text { monoxide }\end{array}$ \\
\hline & Extract with nitric acid & 13.6 & 1.22 & 26.3 & 15.3 \\
\hline & Extract with nitric acid and hydrolyzate & 13.9 & 1.20 & 25.9 & 15.1 \\
\hline 3. & Extract with nitric acio and alcohol & 13.7 & 1.21 & 25.7 & 14.9 \\
\hline 4. & Extract with nitric acid and nitrate & 13.4 & 1.18 & 24.9 & 14.3 \\
\hline 5. & Extract with phosphoric acid & 13.0 & 1.20 & 26.5 & 15.4 \\
\hline 6. & Extract with phosphoric acid and hydrolyzate & 13.3 & 1.18 & 25.9 & 14.3 \\
\hline 7. & Extract with phosphoric acid and alcohol & 13.1 & 1.20 & 26.2 & 14.8 \\
\hline 8. & Extract with citric acid & 13.2 & 1.20 & 26.2 & 15.2 \\
\hline 9. & Extract with citric acid and hydrolyzate & 13.7 & 1.18 & 25.5 & 14.7 \\
\hline
\end{tabular}

tobacco. The delivery of nicotine, tar and carbon monoxide in the smoke was lowest for the nitrate sample. The alcohol and hydrolyzate also decreased the delivery tar and carbon monoxide but to a lesser extent.

\section{CONCLUSIONS}

The following conclusions have been made from comparative laboratory experiments with water pectin extracts from apple pressings and orange peels and commonly applied humectants such as glycerol, diethylene glycol and propylene glycol:

1. The water pectin extracts can be used as tobacco humectants. There were no essential differences in the influence of extracts obtained from the two types of fruit taw materials on the tobacco.

2. The increase in the pectin content of the extract had a positive influence on the water-retentive capacity of tobacco. The best results in this respect were obtained for extracts with $0.5 \%$ and $0.7 \%$ of pectin.

3. The extracting acid also had an influence on the water-retentive properties of tobacco expressed through the index of equilibrium moisture. The equilibrium moisture of tobacco treated with an extract based on nitric acid was greater.

4. The extracts contributed to decreasing the delivery of tar and carbon monoxide in smoke compared to the commonly applied humectants (glycetol, diethyleneglycol and propylene glycol).

5. The fruit extracts had a greater effect on the water-retentive properties of tobacco smoke compared to pectin solutions. The effects of extracts were due not only to their pectin content but also to other substances contained in them.

6. The addition of enzyme hydrolyzate from the fruit raw material, to the extract, also had an effect on the water-retentive capacity of tobacco and the composition of tobacco smoke.

\section{REFERENCES}

1. Kamachi, T., H. Yoshitani, T.Shinkai, and I. Morishita: Studies on tobacco casing. II. Casing effect of polyhydric alcohols. (1); Jap. Monop. Corp. Cent. Res. Inst. Sci. 106 (1964) 285-288.

2. Novikova, L.A., V.G. Veitzeler, and L.N. Anfinigenova: Application of humectants in the tobacco industry. Central Information: Food Processing Industry, Section 13, Tobacco Industry; USSR 5 (1979) 1-16.

3. Smit, H.: Effect of some humectants on the properties of flue cured tobacco; Beitr. Tabakforsch. Int. 5 (1970) 231-238.

4. Viart, P., and C. Clerte: Protecting tobacco from mold. Antifungal formula for tobacco; Ann. Tabac SEITA 11 (1973) 68-75.

5. Wynder, E., and D. Hoffmann: Tobacco and tobacco smoke; Academic Press, New York, London, 1967, 480-484.

6. Louganskaya, L.N.: Casing and flavouring of tobacco. Central Information: Food Processing Industry Section 13, Tobacco Industry; USSR (1968) 1-28.

7. Merory, J.: Food flavouring composition, manufacture and use. Avi. Publ. Comp. Inc. USA (1960) $322-323$. 
8. Yoshitani, H., K. Shimura, S. Wakui, K. Yoshifuji, T. Akaki, T. Shinkai, T. Kamachi, and I. Morishita: Tobacco casing. I. Casing effect of saccharides; Jap. Monop. Corp. Cent. Res. Inst. Sci., Papers 106 (1964) 281-284.

9. Hoffman, S.: Process for preserving cigars and tobacco; U.S. Pat. No 3545453, 1970.

10. Kallianos, A.G., G. Jr. Veasey, and A.H. Warfield: Tobacco casing material; U.S. Pat. No. $3878851,1975$.

11. Tomov, A., and N. Yordanov: The use of softeners to lower the amount of waste in tobacco processing; Bulgarian Tob. 4 (1987) 40-42.

12. Yakounina, S.I.: Application of humectants for tobacco raw material saving; Tabak 2 (1973) 21-23.

13. Georgiev, S.: The effect of some agents on the water-retaining capacity of tobacco; Bulgarian Tob. 11 (1979) 10-14.

14. Godfrey, F.D.: Hydrophobic coating for tobacco sheet material; U.S. Pat. No 4140135, 1979.

15. Kratchanova, M., A. Stoilova, I. Dinkov, and Chr. Kratchanov: Water pectin extracts as softeners in cigarette production: Influence on the chemical composition and tobacco smoke; Bulgarian Chemical Communications 254 (1992) 1487-1490.
16. Panchev J., N. Kirchev, Chr. Kratchanov: Improving pectin technology (II). Extraction using ultrasonic treatment; Int. J. Food Sci. Technol. 23 (1988) 337-341.

17. ISO Standard method No. 2881: Tobacco and tobacco products. Determination of alkaloids in tobacco, 1977.

18. ISO Standard method No. 3400: Determination of alkaloids in smoke condensates, 1989.

19. ISO Standard method No 4387: Cigarettes determination of total and dry particulate matter using a routine analytical cigarette smoking machine, 1987.

20. ISO Standard method No. 8454. Cigarettes determination of carbon monoxide in the vapour phase of smoke (NDIR method), 1987.

Autbors' address:

Higher Instituse of Food and Flavour Industry,

Department of Organic Cbemistry,

Maritza Bouletard 26,

4000 Plovdiv, Bulgaria. 